\title{
MAKNA DESTINASI WISATA DI DUA 'DUNIA': Studi atas Gambaran Dunia Maya dan Fakta Empirik Destinasi Wisata
}

\author{
Oleh: \\ Muhamad Sulhan \\ Departemen Ilmu Komunikasi \\ Universitas Gadjah Mada \\ E-mail: hansul@ugm.ac.id
}

\begin{abstract}
Abstrak
Tulisan ini berupaya mendeskripsikan dan mengelaborasi perbedaan makna yang muncul atas gambaran destinasi wisata dalam dua bentuk. Di satu sisi adalah gambaran dunia maya di dua situs destinasi wisata, di sisi lain adalah gambaran fakta sesungguhnya setelah seseorang datang ke sebuah tempat destinasi. Penelitian sebagai dasar tulisan ini menggabungkan analisis atas dua hal. Pertama, mengambil dan menganalisis isi dua situs resmi dari dua destinasi wisata di Indonesia yang populer dengan menggunakan metode deskriptif kualitatif atas gambar dan kalimat. Kedua, melakukan observasi dan wawancara mendalam terhadap informan yang datang dan menyaksikan sebuah tempat destinasi wisata setelah mendapatkan informasi di laman digital. Analisis atas gabungan dua data tadi berupaya memperlihatkan keunikan, kesenjangan, dan perbedaan antara gambaran dunia maya atas destinasi wisata, dengan opini dan persepsi pengunjung wisata yang telah melihat secara nyata destinasi tersebut. Pemanfaatan media digital telah membuat gambaran sebuah destinasi dengan keunikan tersendiri. Terdapat gambaran yang 'hiperbolik' atas sebuah tempat destinasi. Gambaran yang ternyata menuai kritik, kekecewaan, dan ketidakpuasan setelah seorang pengunjung wisata datang dan menyaksikan sendiri tempat destinasi yang digambarkan dalam dunia maya (blog, situs, fesbuk, twitter, dan lain-lain).
\end{abstract}

Keyword: destinasi wisata, digital communication, hiperrealitas, cyberworld.

\begin{abstract}
This paper tries to describe and elaborate the different meanings that appear on the description of tourist destinations in two forms. On the one hand is a cyberspace image in two sites tourist destinations, on the other hand is a picture of the real fact after someone came to a destination place. The research as the basis of this paper combines two analysis. First, take and analyze the contents of two official sites from two popular tourist destinations in Indonesia by using qualitative descriptive methods of images and sentences. Second, make observations and in-depth interviews of informants who came and witnessed a place of tourist destinations after getting information on digital pages. The analysis of the combined two data attempts to show the uniqueness, the gap, and the difference between cyberspace images of tourist destinations, with the opinions and perceptions of tourist visitors who have seen the real destination. Utilization of digital media has created a description of a destination with its own uniqueness. There is a 'hyperbolic' description of a destination place. The picture that turned out to be criticism, disappointment, and dissatisfaction after a tourist visit came and witnessed their own destinations described in cyberspace (blog, site, Facebook, twitter, and others).
\end{abstract}

Keywords: tourist destination, digital, hiperrealitas, cyberworld.

\section{A. PENDAHULUAN}

Industri pariwisata berkembang pesat di hampir seluruh negara di dunia. Setiap negara berlomba-lomba memperkenalkan keunikan dan kehebatan tempat wisata mereka. Media yang digunakan pun sangat beragam. Hiruk pikuk industri pariwisata ini bertepatan dengan kenyataan semakin 'mengecilnya' dunia. Industri pariwisata juga ditopang oleh 
fakta mobilitas penduduk dunia yang kian hari kian cepat. Berawal dari kemampuan daya angkut pesawat yang semakin banyak, secara otomatis akan menurunkan biaya per penumpang. Sehingga ongkos penerbangan menjadi semakin murah dan ekonomis. Dimulailah sebuah era dimana penduduk dunia menjadi komuter (commuter) melampaui batas negara dengan leluasa. Ditambah dengan kemudahan beragam regulasi antar negara, hingga saat ini diperkirakan 10 juta turis aktif bergerak dari satu negara menuju negara lain. Inilah pangsa pasar industri pariwisata abad ini. Yang tidak bisa dilupakan, pemantik bergeraknya jutaan manusia itu adalah informasi tentang destinasi wisata yang bisa diakses dengan cepat. Teknologi informasi dan komunikasi memberi kontribusi signifikan akan hal itu.

Setiap orang yang akan bepergian untuk keperluan wisata, pada dasarnya telah memiliki rencana dan perhitungan keuangan (finansial) yang jelas. Mereka mengetahui dengan pasti ke titik mana mereka akan pergi, dalam waktu berapa lama, dan dengan menggunakan moda transportasi seperti apa. Semua secara detail direncanakan. Terlepas mereka melakukan perjalanan seorang diri maupun bersama kelompok. Seiring perkembangan teknologi informasi dan komunikasi, mereka membutuhkan sumber informasi yang bisa dipercaya tentang segala aspek perencanaan wisata mereka. Internet memberikan semua itu. Melalui media mutakhir ini, tidak ada lagi informasi tentang sebuah destinasi wisata (terkenal) di dunia yang tidak diketahui. Seseorang yang akan bepergian dengan gampang membuka laptopnya, membuka google, lalu mengetikan beragam kata kunci untuk mengetahui segala hal terkait tempat, biaya, alokasi waktu, dan sebagainya. Perjalanan menjadi semakin menyenangkan, karena garansi kebenaran informasi.

Informasi di media internet bisa berasal dari beragam sumber. Baik dari sesama traveller, blogger, maupun dari organisasi resmi yang memiliki otoritas memberikan informasi tentang pariwisata. Kadar kepercayaannya pun menjadi tidak sama. Beberapa orang lebih yakin dan percaya dengan informasi sesama traveller melalui situs-situs pribadi semacam blogspot.com, maupun wordpress.com. Sementara beberapa orang yang lain lebih percaya pada situs-situs yang dikelola instansi resmi. Entah itu situs agen travel maupun situs pemerintah setempat di negara yang akan mereka kunjungi. Biasanya tingkat kepercayaan ini muncul karena adanya kerangka referensi (frame of reference) positif yang mengarahkan mereka untuk begitu. Selain juga karena bidang pengalaman (field of experience) positif di titik lain. Dengan orientasi positif dari dua faktor ini, seseorang akan mudah sekali untuk datang mengunjungi sebuah destinasi wisata. Kerangka referensi positif akan memantik minat seseorang untuk datang ke sebuah tempat wisata. Setelah mereka berkunjung ke tempat tersebut, segala pengalaman tentang proses kunjungan dan kesan terhadap tempat kunjungan akan mereka sampaikan kepada orang lain. Melalui media sosial, semua itu begitu gampang dilakukan. Industri pariwisata berkembang karena kekuatan word of mouth (WOM) otomatis yang terjadi antar traveller. Setiawan \& Savitry (2016) menyebut ini kekuatan para advocate, yakni seseorang yang dengan senang hati membagikan (sharing) segala pengalaman itu kepada orang lain. Disadari atau tidak, kekuatan para advocate ini menjadi sentral dalam distribusi informasi destinasi wisata. Tak jarang informasi dari sebuah situs resmi sebuah destinasi wisata kalah populer dengan sebuah situs blogger saat seorang wisatawan akan mencari informasi tentang destinasi. Saya menyebut ini titik pemantik kepercayaan (trust trigger activation). 
Sebuah destinasi wisata akan berkembang jika konten informasi antara sumber informasi utama (situs resmi otoritas destinasi) memiliki informasi yang kurang lebih bermakna sejajar dengan informasi di ruang media sosial para advocate. Bagaimana kemudian jika terjadi perbedaan signifikan antara konten informasi antara situs resmi pemegang otoritas sebuah destinasi wisata, dengan situs-situs pribadi para advocate? Bagaimana jika muncul perbedaan story yang signifikan antara apa yang digambarkan sebuah situs resmi sebuah destinasi dengan paparan cerita seorang advocate yang telah berkunjung ke destinasi tersebut?

Ada tiga kemungkinan kondisi yang akan muncul seiring dengan perbedaan tadi. Pertama, seorang calon wisatawan akan lebih percaya pada situs resmi pemegang otoritas dari pada situs para advocate; kedua, calon wisatawan lebih percaya pada situs para advocate daripada situs resmi pemegang otoritas destinasi; ketiga, calon wisatawan memilih opsi untuk terus menghimpun sebanyak mungkin informasi yang sama dari beragam sumber untuk menjadikan informasi terbanyak sebagai panduan kebenaran atas sebuah tempat destinasi. Jika opsi yang ketiga terjadi, maka sangat dimungkinkan sumber informasi dari pemegang otoritas destinasi akan kalah bersaing dengan tingkat detailitas dan kelengkapan informasi dari para advocate (blogger, traveller). Pertanyaan lebih jauh adalah bagaimana tingkat keakuratan, kelengkapan, detilitas, yang ditampilkan setiap sumber informasi tersebut? Sejauh mana para kreator informasi dari pemegang otoritas telah menyusun dan menggambarkan destinasi wisata dalam situs mereka? Pertanyaan pertama memantik keingintahuan atas kompleksitas situs-situs resmi berisi informasi tentang destinasi wisata. Sementara pertanyaan kedua membutuhkan penjelasan lebih komprehensif dari para penanggung jawab (kreator) situs ruang maya tersebut. Orientasi dari jawaban atas dua pertanyaan tadi adalah untuk mengetahui bagaimana dan mengapa keberadaan situs-situs yang berbeda cerita (story) atas sebuah destinasi wisata yang sama, bisa memunculkan cerita dan anggapan yang berbeda dari pengunjung wisata saat mereka benar-benar telah datang dan berkunjung ke destinasi tersebut. Tak jarang, opini dan anggapan atas sebuah tempat destinasi bernada negatif. Kecewa karena fakta nyata destinasi wisata tidaklah seindah dan sebagus gambaran di dunia maya.

Secara teoretik, ada hal menarik yang membuat dua titik pemantik kepercayaan (FOR \& FOR) itu berubah menjadi negatif. Tentu semua wisatawan dan traveller memahami bahwa tidak semua fakta di lapangan bisa seindah tampilan gambar, warna, dan suasana yang tercipta pada foto, tulisan, dan aspek konten yang tersedia di sebuah situs. Mereka bisa memahami hal itu. Pemahaman itu ternyata tetap saja memunculkan sentimen negatif yang tergambar melalui paparan cerita mereka dalam situs-situs pribadi, sehingga menjadi viral di media sosial. Jika sudah menjadi viral, maka kampanye negatif atas sebuah destinasi wisata telah tercipta. Ini artinya, ditengah hiruk pikuknya pemegang otoritas destinasi wisata membangun strategi komunikasi melalui media sosial, pengabaian tentang kelengkapan, detailitas informasi sebuah destinasi wisata haruslah digarap dengan serius. Jika tidak, maka terjadi peralihan kepercayaan dari para wisatawan menuju pada situs-situs pribadi yang lebih lengkap dan mungkin mengangkat isu yang berbeda. Ini menuntut antisipasi. Agar tidak terjadi penggunaan ruang informasi menuju pada kampanye negatif sebuah destinasi. Segala tingkat kemungkinan sebagai pemicu kampanye negatif semacam itulah yang layak untuk ditelusuri asal muasalnya, prosesnya, sehingga bisa diidentifikasi 
sumber, penyebab, dan rekomendasi mengatasinya. Penelitian ini berupaya meraih langkah pertama untuk mengetahui bagaimana pemantik kemungkinan negatif itu muncul dan cenderung berkembang. Formulasi sederhana yang akan ditempuh adalah dengan memberikan kemungkinan atas ragam makna yang muncul melalui unjuk tampil informasi destinasi wisata melalui situs dan website resmi pemerintah. Instansi terakhir ini adalah organisasi yang memiliki otoritas untuk menjaga dan mengelola sebuah destinasi wisata. Selanjutnya tulisan ini akan melihat ragam opini dari para pengunjung destinasi, yang mengalami sensasi perbedaan kenyataan situasi dan kondisi tempat destinasi wisata dengan gambaran di situs maupun media lain di dunia maya.

\section{B. TINJAUAN PUSTAKA}

Tinjauan pustaka ini terdiri atas rangka teoretik untuk memperjelas kontribusi media digital dalam industri pariwisata, dan bagaimana kemudian konsep hiperrealita dipinjam untuk membaca ulang tampilan sebuah situs destinasi wisata. Dalam proses mengulas dua rangka utama tadi akan dijabarkan beragam penelitian yang telah dilakukan terkait relasi antara dunia digital dengan industri pariwisata. Namun untuk memberikan gambaran betapa menariknya proses komunikasi untuk mengkampanyekan sebuah destinasi wisata, perlu kiranya diuraikan ragam tinjau pustaka terkait komunikasi pemasaran dan destinasi wisata terlebih dahulu.

\section{Brand Destinasi dan Strategi Komunikasi Pemasaran Destinasi}

Tulisan dan laporan-laporan hasil kajian destinasi dan strategi komunikasi pemasaran destinasi, baru dapat dibaca melalui jurnal ilmiah setelah tahun 2000. Dengan kata lain, sejak tahun-tahun itu telah lahir aliran-aliran kritis dan postmodern yang secara kuat memengaruhi jalan pikiran masyarakat dunia. Kajian tentang brand destinasi ataupun strategi komunikasi pemasaran destinasi, baru diketahui ada sejak tahun 2004. Tulisan kajian yang benar-benar mengkaji citra brand destinasi baru diketahui ditulis oleh Graham Hankinson (2004). Kemudian pada tahun-tahun berikutnya, karya-karya serupa mulai banyak dibincangkan orang, kala itu, pemikiran-pemikiran kritis dan postmodern telah ada dan ikut mewarnai pemikiran-pemikirani lmuwan dalam mengulas gagasan-gagasan mereka itu.

Walaupun demikian dapat disimpulkan, tulisan-tulisan itu mengkaji hal-hal berikut; (1) konsep pemasaran (Hermawan, 2006, Kotler, 2006); (2) konsep brand dan branding destinasi (Alserhan, 2010, Anholt, 2011, Balakrishnan, 2008, Balakrishnan, Nekhili \& Lewis, 2011, Byon\& Zhang, 2010, Chiu, 2010, Hankinson, 2004, Hankinson, 2005, Hosany, Ekinci\&Uysal, 2007, Hansen \&Machin, 2011, Ibrahim, Muhammad \& Ahmad, 2008, Insch, 2010, Loo \& Davies, 2006, Lucarelli\& Berg, 2011, Morgan, Pritchard \& Pride, 2011, Osei\&Gbadamosi, 2011, Peterson, 2006, Pike, 2005, Popy, 2007, Pike, Bianchi, Kerr \& Patti, 2010, Ruzzier, 2010, Ryan \& Silvanto, 2011, Satya, 2007, Wisansing, 2005, Wilson \& Liu, 2011); (3). strategi branding dalam proses komunikasi brand destinasi (Balakrtishman, 2009, Dinnie, Melawar, Seidenfuss \& Musa, 2010, Gertner, Berger \&Gertner, 2006, Haven-Tang, Jones \& Webb, 2007, McCartney, 2008, McCartney, Butler \& Bennett, 2008, Norhafezah, 2008, Puczko, Ratz\& Smith, 2007, 
Simpson \&Sigiuaw, 2008, Tita, 2008, Vitic\& Ringer, 2007, Vellas \& Becherel, 2008, Wang, 2008); (4). konsepdestinasidanstakeholder (Huang, 2011, Marzano, 2006, Saraniemi, 2011, Wan \& Chang, 2009); dan (5). Persepsi dan pengalaman wisatawan (Fanggy\& Richardson, 2011, Kalsom, 2008, Martin \& Woodside, 2011).

Dari sudut metode penelitian yang digunakan, metode yang digunakan amat beragam sesuai dengan sudut pandang dan kepentingan kajian yang dilaksanakan. Keragaman itu dijumpai pada metode yang digunakan dari tahun ke tahun, seperti pada umumnya metode yang digunakan adalah deskriptif, baik kuantitatif maupun kualitatif serta kajian pustaka. Berawal dari kajian Hankinson (2004), Loo dan Davies (2006), Pike (2005), Wisansing (2005), mereka menggunakan metode deskriptif, kemudian Peterson (2006) menggunakan metode kajian kasus, Marzona dan Scott (2005) dan Rufidah (2007) menggunakan hermeneutik, Satya (2007) menggunakan metode dokumentasi. Balakrishman (2008), Saraniemi (2011), Tita (2008), menggunakan kajian kasus Balakrishman (2009) kualitatif-bahan pustaka. Hansen dan Machin (2011), Lusi (2008) menggunakan metode kualitatif-critical discourse dan analisis wacana. Wang (2008) menggunakan kualitatif. Anholt (2011), Huang (2011), Insch (2010), Kalsom (2008), McCartney (2008), Shiu (2010), menggunakan metode deskriptif. Dinnie, Melawar, Seidenfuss dan Musa (2010), Ibrahim, Muhammad dan Ahmad (2008), Vellas dan Becherel (2008), menggunakan metode kualitatif wawancara mendalam. Pike, Bianchi, Kerr, dan Patti (2010), menggunakan metode tahan CBBE, Alserhan (2010), Lucarelli dan Berg (2011), Osiedan Gbadamosi (2011), menggunakan kajian kepustakaan dan penelusuran literature. Martin dan Woodside (2011) menggunakan metode analisis isi, Wilson dan Liu (2011) menggunakan metode kualitatif-analisis fenomenologi dan analisis wacana kritis. Adapun Vitic dan Ringer (2007) menggunakan SWOT.

Kemudian pada tahun 2004-2005, Byondan Zhang (2010) menggunakan kuantitatif-SEM. Gertner, Berger, dan Gertner (2006) menggunakan metode kuantitatif penguraian. Hankinson (2004), Hankinson (2005), mencoba menggunakan kuantitatif, analisisisi, dan analisis factor. Hosany, Ekinci, dan Uysal (2007) menggunakan metode kolerasi. Puczko, Ratz, dan Smith (2007) menggunakan kuantitatif-multitingkat. McCartney, butler dan Bennett (2008) menggunakan metode quantitative-communication effectiveness. Silvanto (2011) menggunakan kuantitatif-multivariat. Hanya ada satu kajian saja yang menggunakan gabungan kualitatif-kuantitatif, yaitu Heven-Tag, Joneddan Webb (2007).

Nampak dari sebaran ragam tema penelitian dan juga metode penelitian yang digunakan, penelitian ini tidaklah bisa dikatakan baru. Dalam arti memiliki sebuah keunikan yang benar-benar orisinal dari seluruh pustaka di atas. Penelitian ini berupaya menyajikan proposisi bahwa banyak informasi dan tampilan di situs pengelola wisata resmi di sebuah wilayah destinasi ternyata memungkinkan hadirnya beragam makna, yang muncul dari kecenderungan manipulasi fakta sesungguhnya. Manipulasi atas fakta tadi bukanlah semata diiringi dengan sebuah kesadaran, namun lebih disebabkan teknologi determinasi di bidang komunikasi. Lebih tepatnya muncul karena kehadiran dan kompleksitas media baru.

\section{Media Digital dan Destinasi Wisata}


Seiring dengan perkembangan dan kontribusi teknologi informasi dan komunikasi dalam dunia pemasaran, maka industri pariwisata pun bergerak untuk memanfaatkan teknologi tersebut. Terutama pada sektor komunikasi. Beberapa stakeholders yang berkepentingan dalam dunia pariwisata telah mulai terbiasa dengan penggunaan perangkat keras dan lunak dalam mempromosikan produk, desninasi wisata, dan ragam layanan jasa. Menyambut gegap gempitanya abad informasi, aktivitas pariwisata pun tidak terlepas dari perkembangan kemajuan internet dan komunikasi pemasaran (Kertajaya,2013). Intinya, penggunaan media sebagai strategi branding sudah niscaya. Meskipun bermula dari sektor swasta, pada akhirnya sektor pemerintah juga tergerak untuk mempergunakannya. Tak terkecuali bidang kementerian pariwisata. Fenomena menggencarkan kekuatan media dalam mengomunikasikan destinasi wisata tampak meningkat dalam dua dekade terakhir. Ini pertanda bagus. Setelah begitu banyak informasi destinasi wisata diperoleh melalui konten yang ditulis para blogger, beberapa situs resmi destinasi wisata yang dikelola pemerintah kemudian mulai meningkatkan layanannya. Tidak semata-mata sebagai sebuah situs statis (hanya tampil laman home semata namun tidak ada aktivitas di dalamnya), namun sudah lebih aktif dalam meng-upgrade dan memperbaharui terus menerus konten dan aktivitasnya.

Untuk membangun sebuah isi pemasaran (marketing content) yang sukses, setiap pemasar perlu melihat delapan tahap ideal yang selama ini diamini sebagai landasan melakukan kegiatan komunikasi pemasaran di era digital. Setiawan \& Savitry (2016) menegaskan pentingnya memperhatikan delapan hal dalam melakukan kegiatan pemasaran. Seorang pemasar harus menetapkan tujuan (determine objective), memetakan target (target mapping), menentukan tema besar dari konten tersaji (content ideation), menentukan kapan dan siapa yang membuat konten (content creation), mendistribusikan konten (content distribution), memperkuat konten (content amplification), evaluasi (content evaluation), dan mengembangkan konten (content improvement). Terlepas dari taat atau tidaknya seorang pengelola situs destinasi wisata menerapkan delapan langkah tadi, fakta menunjukan beberapa destinasi wisata di provinsi-provinsi di Indonesia mengalami kemajuan seiring dengan pengelolaan situs destinasi yang semakin baik. Ini menunjukan adanya relasi signifikan antara pengelolaan dunia digital dengan kemajuan pariwisata di alam nyata. Sebuah fakta yang sebelumnya sudah cukup serius diramalkan dalam beragam kajian teoretik tentang kebergunaan media baru dalam dunia pemasaran (Menzies, 1998; Lamberton, 2006; Yananda \& Salamah, 2014). Konsep utama yang menghubungkan antara dua hal itu adalah kecenderungan bagaimana informasi disampaikan dalam perkembangan teknologi komunikasi sedemikian rupa. Informasi tentang destinasi wisata di sebuah situs menjadi ruang kaji baru yang sangat menarik.

Karya-karya maupun penelitian yang menghubungkan antara destinasi wisata dengan strategi komunikasi pemasaran secara langsung belum banyak dilakukan. Masingmasing karya berdiri sendiri sebagai sebuah proyek penelitian maupun karya tulis. Berkaitan dengan signifikansi konsep positioning sebuah brand dalam konteks pemasaran dan komunikasi pemasaran pariwisata. Pembahasan tentang positioning berasal dari dunia pemasaran produk dan jasa (Ries \& Trout,2002), yang didasari oleh prinsip kompetisi dari setiap brand untuk memperebutkan ruang di dalam pikiran setiap konsumen. Hanya brand yang kuat-lah yang mampu menempati top mind dari memori seseorang. Begitu gagasan 
positioning dilemparkan ke dunia komunikasi pemasaran, maka prinsip positioning dilakukan hampir seluruh produk dan jasa yang dikomunikasikan. Termasuk di dalamnya destinasi wisata sebuah negara (Heath \& Wall,1992; Kartajaya \& Nirwandar, 2013). Salah satu temuan menarik adalah penelitian I Gusti Ngurah Widyatmaja (2010) yang secara kritis mencermati kebijakan positioning brand destinasi nasional Indonesia yang menurutnya telah kontraproduktif dengan upaya pemerintah pusat mengomunikasikan identitas tunggal pariwisata nasional. Dalam pengamatan Widyatmaja, justru inkonsistensi brand destinasi negara Indonesia yang mudah sekali berganti-ganti dalam satu dekade terakhir membuat identitas Indonesia tampil membingungkan di mata wisatawan. Penggantian positioning brand destinasi yang mudah sekali dilakukan (tanpa perencanaan dan analisis mendalam) pemerintah pusat membuat Indonesia selalu kalah dengan Malaysia yang selalu setia dengan tagline "Trully Asia” mereka. Widyatmaja memvonis inkonsistensi positioning itulah yang membuat angka kunjungan wisman di Indonesia tidak pernah bisa melebihi Malaysia, Thailand, dan Singapura.

Strategi pemosisian (positioning) sebuah brand merupakan suatu keputusan strategis, karena hal ini akan sangat mempengaruhi keberhasilan produk tersebut dalam meraih sukses dalam jangka panjang (Hawkins dan Best, 1998). Dalam hal ini yang dimaksud adalah bagaimana produk tersebut diharapkan akan dipersepsikan oleh pasar yang dijadikan sasaran relatif terhadap para pesaingnya dan ekspektasinya. Shostack (1987) bahkan mengemukakan bahwa dalam situasi persaingan yang semakin tajam, strategi pemosisian produk merupakan tugas yang paling kritis yang harus dihadapi oleh seseorang pemasar.

Demikian pula halnya dengan Heath and Wall (1992) yang menyatakan arti pentingnya pemosisian (positioning) suatu daerah tujuan wisata sedemikian rupa sehingga unit-unit usaha dan lembaga-lembaga terkait (stakeholders) di daerah tersebut dapat memahaminya dengan baik dan segera dapat menyesuaikan strateginya dengan strategi pemosisian (positioning) daerah dan bahkan negara tujuan wisata tersebut. Nilai penting positioning dalam pengomunikasian identitas destinasi wisata sebuah wilayah itulah yang menjadi sentral penelitian ini.

\section{Hiperrealitas Destinasi sebagai Ruang Negosiasi "Definisi"}

Hiperrealitas merupakan sebuah dunia realitas yang dalam konstruksinya tidak bisa dilepaskan dari produksi dan permainan bebas tanda-tanda yang melampaui (hyper-sign) sebuah tanda yang melampaui prinsip, definisi, struktur, dan fungsinya sendiri (Piliang, 2003). Lebih jauh Piliang menegaskan bahwa dunia hiperrealitas dapat dipandang sebagai sebuah dunia perekayasaan (dalam pengertian distorsi) realitas melalui hyper-signs, sedemikian rupa, sehingga tanda-tanda tersebut kehilangan kontak dengan realitas yang direpresentasikannya. Dengan demikian hiperrealitas menyiptakan satu kondisi, yang di dalamnya kepalsuan berbaur dengan keaslian, masa lalu berbaur dengan masa kini, fakta bersimpang siur dengan rekayasa, tanda melebur dengan realitas, dusta bersenyawa dengan kebenaran. Berbekal pemahaman Jean Baudrillard tadi, Piliang (2003) menegaskan bahwa dalam hiperrealitas, kategori-kategori kebenaran, kepalsuan, keaslian, isu, realitas seakan tidak berlaku lagi dalam dunia seperti itu. Titik menarik dari proses hiperrealitas itu adalah strategi rekayasa atas fakta yang dimunculkan dalam simbol dan tanda. Proses manipulasi 
ini pada dasarnya selalu melibatkan media dengan segala kepentingannya (Slouka, 1995; Gray, 2006; Chomsky, 2015; 2017).

Umberto Eco $(1976 ; 1987)$ menyebut semiotika sebagai sebuah disiplin yang mempelajari segala sesuatu yang dapat digunakan untuk berdusta (lie). Banyak analisis yang diberikan atas definisi kontroversi tersebut. Piliang (2010) menggarisbawahi bahwa Eco sebenarnya tengah memainkan logika oposisi biner saat memberi definisi tadi. Jika sesuatu bisa digunakan untuk menyampaikan dusta, maka dia juga bisa digunakan untuk mewartakan kebenaran. Sebuah keseimbangan. Tinggal bagaimana mensiasati proses penyampaian, dan apa tanda, lambang, dan simbol yang digunakan untuk berdusta tersebut. Dengan menggunakan Oxford Advanced Learner's Piliang membedah makna dusta untuk memaparkan kemampuan tanda untuk memberitahu tentang realitas. Menurutnya, tetap terdapat jurang yang dalam antara sebuah tanda (sign) dan referensinya terhadap realitas (referent). Konsep, isi, atau makna dari apa yang dibicarakan atau ditulis tidak sesuai dengan realitas yang coba untuk dilukiskan. Yang menarik adalah daya kritik Piliang terhadap gagasan kedustaan Eco. Menurutnya, relasi antara tanda dan realitas tidak sematamata bersifat binari sederhana. Terdapat konsep muatan kedustaan (pseudo) yang disampaikan semata-mata ketidaklengkapan tanda dalam mengungkap sebuah realitas. Ini bukan tentang dusta dan kebenaran. Ini adalah tentang kepalsuan yang muncul dalam ungkapan realitas. Sebuah tanda berpretensi mengungkapkan realitas padahal ungkapan tersebut palsu, dalam pengertian ia seolah-olah sudah merepresentasikan realitas, padahal baru sebagian kecil unsur realitas tersebut, atau mungkin permukaan luarnya saja yang direpresentasikan. Contohnya rambut palsu atau gigi palsu. Simpulnya, sebuah tanda dalam hal ini tidak mendustakan realitas, namun memalsukan realitas. Dalam rumus Piliang, dikatakan bahwa [A'] padahal sebenarnya realitasnya adalah [A]. Bisa dikatakan bahwa realitas telah dimanipulasi sedemikian rupa dengan beragam tujuan, atau sebatas ketidaklengkapan pengetahuan.

Sebuah realitas destinasi wisata adalah ruang maha kompleks tentang sebuah tempat. Tempat (place) dalam hal ini tidak semata-mata merujuk pada konteks geografis keberadaan posisi. Tempat bersinonim dengan ruang ekologis yang ditampung oleh struktur tempat tadi. Pada sebuah destinasi wisata terdapat beragam fenomena yang terhampar untuk digambarkan. Ada lanskap alam yang eksotik (gunung, pantai, jurang, lembah, dan bentang alam), ada suasana kehidupan sosial budaya masyarakat yang unik (desa wisata, tarian tradisional, tradisi dan kebiasaan masyarakat setempat), ada artefak bersejarah dengan segala mitos dan lagenda yang mempesona (patung, candi, arca, dan sebagainya). Semua menjadi ruang ekologis yang tak mudah ditampung dalam sebuah laman atau sehalaman buku cerita. Dibutuhkan banyak versi dan jalinan cerita di sana.

Jalinan cerita dan rangkaian narasi bebas yang berkembang di dalam situs dan blog pribadi sebenarnya menjadi ciri dari dinamika komunikasi pariwisata. Dan itu muncul karena pergeseran signifikan akan makna jurnalistik era digital yang mau tak mau harus diterima sebagai sebuah realitas kekinian. Kebebasan seorang yang memiliki media pribadi dan personal (media sosial) membuat dia tidak terlalu terikat dengan ragam norma dan aturan jurnalistik. Ryan Holiday (2012) secara eksterm menamakan praktek ini dengan istilah media manipulatif. Para pelakunya adalah komplotan manipulator fakta dengan muara keuntungan ekonomi semata. Holiday menguraikan 9 (sembilan) taktik yang 
digunakan para media manipulator untuk menyamarkan fakta, lalu menggantikannya menjadi sebuah rekayasa atas kenyataan sesungguhnya. Sembilan taktik tadi semata berujung pada kenyataan hasil rekaan dan kesepakatan. Bagi sosok seperti Holiday, kinerja media tak lain dan tak bukan adalah sebuah institusi bermakna khusus sebagai penyipta sebuah kenyataan semu, sehingga ia benar-benar dianggap sebuah kenyataan. Para blogger memainkan peran signifikan dalam narasi kenyataan di masa depan. Pada akhirnya yang tersisa adalah permainan makna akan sebuah informasi yang sama-sama diketahui sebagai sebuah kesemuan fakta (pseudo-event).

Terkait dengan kontribusi analisis teks (semiotik) dalam industri pariwisata, maka konsep yang akan segera terhubung adalah terkait dengan positioning sebuah brand destinasi. Mengingat tempat (place) yang dipublikasikan dalam sebuah kampanye pemasaran pada dasarnya adalah juga sebuah merek (brand). Untuk itulah elaborasi konsep brand destinasi akan menjadi titik pijak dalam tinjauan pustaka ini. Telaah atas brand destinasi sebagai sebuah karya semiotik mengulas tanda bisa dijumpai dalam beragam mazhab pemikiran. Bermula dari pemikiran Gamson, Croteau, Hoyner, \& Sasson (1992) yang melakukan kajian tentang perkembangan media gambar di Amerika Serikat dengan meneliti pembaca media gambar dengan menggunakan metode hermeneutika. Simpul dari kajian mereka menyebutkan bahwa makna konstruksi sosial terhadap realitas gambar adalah hal terpenting dari sebuah pesan visual yang lebih umum. Artinya fokus perhatian pada gambar menghubungkan seseorang dengan sosok lain dalam arti yang lebih luas dibanding sebatas relasi interpersonal. Hal itulah yang kemudian terjadi saat setiap orang melihat simbol dan tanda yang terhubung dengan identitas Amerika. Muncul makna tertentu pada diri setiap orang saat terpapar pesan komunikasi yang dikreasi untuk merepresentasikan image positif negara Amerika.

Positioning selalu berkaitan dengan keunikan dan diferensiasi brand. Dalam kaitannya dengan destinasi, brand dibentuk dengan konfigurasi gambar (visual), tulisan (aksara), dan aksentuasi (seni) yang unik. Secara manifes itu dinamakan dengan brand destinasi negara (BDN). Pada sebuah BDN selalu terkandung unsur simbol dan tanda tertentu, yang mengandung arti bahkan begitu luas untuk merepresentasikan image positif sebuah negara. Penelitian Bungin (2010a) tentang identitas destinasi wisata di Banda Neira mengetengahkan nilai penting brand positioning sebuah tempat sebagai unsur utama menarik pengunjung untuk datang. Hal yang sama dilakukan oleh Wisangsing (2005) saat menelisik tentang branding destinasi Malaysia. Prinsip penelitian itu juga dilakukan oleh Peterson (2006) untuk melihat brand positioning Qatar melalui langkah konstruksi citra. Sementara Loo \& Davies (2006) menelisik dengan cara yang sama untuk mengungkap branding destinasi China. Rata-rata hasil kajian mereka mengindikasikan pentingnya sebuah langkah konstruktif menyiptakan dan mensosialisasikan BDN. Ragam penelitian yang dilakukan mengarah pada menguatnya perhatian pada unsur pesan (teks) dalam elaborasi tentang destinasi wisata. Terutama teks terkait publisitas tempat-tempat destinasi tersebut. Pemahaman tentang kekuatan kajian semiotika layak dipertimbangkan dalam menelusuri pesan-pesan pemasaran pariwisata.

Setiap destinasi wisata selalu memiliki cerita tersendiri pada setiap orang yang bermain dan berkunjung di sana. Melalui perkembangan konvergensi media, setiap orang yang berkunjung ke sebuah tempat pada dasarnya berupaya keras untuk 'memaku waktu' 
menyampaikan kisah untuk mendokumentasikan ragam pengalam mereka. Seperti yang dipaparkan Andre Mokalu (2017) bahwa sebuah perjalanan ke sebuah tempat wisata di berbagai negara pada dasarnya tidak berpeluang memberi pengetahuan pada seseorang tentang cara-cara travelling. Di dalam setiap perjalanan selalu terkandung romansa perjalanan pribadi yang berkelindan kesedihn, kebahagiaan hingga luapan emosi sedemikian rupa dari setiap pelakunya. Rasa itulah yang kemudian turut memberi warna pada strategi penceritaan seseorang atas sebuah destinasi wisata. Tak perduli bagaimana fakta nyata tempat, kondisi, dan bangun fisik sebuah tempat yang dikunjungi, seorang blogger atau wisatawan amatir akan cenderung membingkai sebuah tempat destinasi sesuai dengan frame yang dia yakini. Inilah hal menarik yang membuat sebuah tempat wisata terceritakan selalu sejajar dengan frame sang pencerita.

\section{METODE PENELITIAN}

Penelitian ini menggunakan dua metode sebagai cara memahami kompleksitas objek penelitian. Landasan pemikirannya adalah pemahaman Poynter (2012) tentang analisis teks pada media baru, untuk kemudian digunakan sebagai landasan meneliti realitas empirik. Pertama, metode analisis isi kualitatif digunakan untuk mengulas makna secara deskriptif atas aspek semantik hingga pragmatik yang terdapat pada laman home (beranda) dua buah situs destinasi wisata yang dikelola oleh institusi resmi pemerintah. Laman website yang menjadi objek penelitian ini adalah (1). www.ntbprov.go.id sebagai situs resmi provinsi Nusa Tenggara Barat (NTB), dan (2). www.jatengprov.go.id merupakan situs resmi pemerintah provinsi Jawa Tengah. Dua situs ini akan menjadi objek studi teks terkait dengan laman bidang pariwisata yang terdapat pada situs tersebut. Analisis akan meliputi rangkai kata dan gambar yang menimbulkan image pariwisata wilayah tersebut sebagai sebuah destinasi. Metode analisis isi ini akan digunakan dalam konteks semantik sepanjang menyangkut aspek manifes dari rangkai tanda dan simbol yang terdapat pada laman pariwisata di dua situs terteliti. Sementara terkait dengan kompleksitas relasi makna antara objek, representamen, dan interpretant akan menjadi ranah analisis pada level pragmatik.

Metode kedua yang digunakan dalam penelitian ini terkait objek empirik yang akan diteliti. Objek empirik yang dimaksud adalah observasi langsung pada beberapa situs destinasi wisata di kedua wilayah yang diteliti. Peneliti telah melakukan observasi pada tiga titik destinasi di wilayah Jawa Tengah, yaitu Candi Borobudur, Punthuk Sedatu, Tawangmangu, dan candi Sukuh, di Provinsi Jawa Tengah. Lalu untuk wilayah provinsi Nusa Tenggara, peneliti telah melakukan observasi di area destinasi wisata desa Sembalun, Lombok, pantai Senggigi, Gili Terawangan, dan pantai-pantai di Sumbawa Barat. Dua metode penelitian di atas akan digunakan secara komprehensif untuk mencapai tujuan penelitian. Meskipun ungkapan 'manipulasi' tidak sepenuhnya dimaksudkan sebagai sebuah unsur kesengajaan dari admin dan pengelola situs destinasi wisata, namun dialog untuk mengungkap ruang-ruang hiperrealita teks dan simbol akan menjadi temuan yang dijanjikan dalam tulisan ini. 


\section{PEMBAHASAN}

Kemudahan dan kenyamanan akses atas pencarian informasi untuk sebuah lokasi destinasi wisata saat ini merupakan buah panjang dari perkembangan teknologi. Tentu saja bukan semata kemudahan dan kelengkapan informasi yang patut menjadi sorotan, melainkan pada konstruksi makna yang kemudian muncul seiring dengan bertambah banyak dan masifnya informasi yang dihadirkan. Sambil terus melakukan rangkai renung atas strategi komunikasi destinasi wisata yang terdapat pada beberapa situs dan website terteliti, pembahasan ini selalu kembali pada biasnya penyajian informasi yang muncul pada berbagai bukti yang dihadirkan laman-laman tersebut.

\section{Serangan Dunia Digital: Saat Destinasi Wisata Menjadi Sekadar Citra}

Pada dasarnya media adalah pencerita. Fungsi naratif yang dimainkan media di sini memiliki implikasi penanaman arti dan bahkan ideologi. Jika pada masa lalu struktur makna biasa mengacu pada sosok opinion leader yang menjadi patokan khalayak, dunia masa kini telah meniadakan otoritas tadi. Dalam konteks media baru (new media) kekuatan untuk menentukan narasi dan membingkai makna itu tadi berlangsung lebih kuat, lebih personal, dan memiliki kekuatan revisi yang tiada henti. Itu artinya, sebuah narasi di dalam media baru sebagai sebuah informasi sama sekali tidak memiliki nilai tetap. Mudah sekali digantikan seiring dengan informasi baru yang terus ditambahkan. Terlebih pada era digital informasi dan komunikasi seperti saat ini.

Jika pemahaman konseptual di atas dikaitkan dengan sebuah destinasi wisata, maka jelas bahwa setiap tempat dan wilayah pastilah membutuhkan diferensiasi. Tujuannya untuk menciptakan struktur memori khas yang akan terpahat di kepala pengunjung. Bayangkan betapa banyak destinasi wisata di Indonesia yang tampilan fisik geografiknya berbentuk pantai, gunung, lembah, dan air terjun. Sebagai sebuah artefak, semua jenis destinasi tadi akan memantik kebingungan bagi pengunjung. Uniknya, pada setiap pantai, lembah, air terjun, para wisatawan selalu memiliki narasi masing-masing yang berbeda-beda. Mereka bisa dengan cepat membedakan antara nuansa pantai di Senggigi, Lombok dengan pantai di Kuta, Bali. Demikian pula halnya dengan destinasi wisata berujud candi. Wisatawan dengan cepat bisa memanggil kembali memori mereka saat harus membedakan setiap candi yang mereka kunjungi. Bukan pada kontur candi secara fisik, melainkan pada narasi yang mengiringi perjalanan mereka menikmati setiap sudut dan kontur candi. Inilah kekuatan diferensiasi. Titik diferensiasi inilah yang distimulan oleh positioning dalam strategi komunikasi pemasaran destinasi wisata.

Destinasi wisata pada gilirannya tidak lagi semata-mata hanya berupa fisik geografis, melainkan sudah menjadi ruang terbuka petualangan psikis kejiwaan. Melalui sarana naratif, seluruh wilayah destinasi wisata telah membuka diri agar bisa diceritakan sedemikian rupa oleh para pengunjungnya sendiri di setiap laman media sosial mereka. Langkah tersebut bukan saja sangat strategik, melainkan juga sangat cerdas ditengah keterbatasan sumber daya manusia yang menjadi admin setiap website resmi pemerintah daerah wilayah destinasi wisata. 
Peran serta media digital dalam konteks promosi destinasi wisata sudah sangat konkret. Melalui sifat masif dan freedom dari media sosial, setiap orang saat ini telah menjadi 'advocate' bagi sebuah destinasi wisata. Rangkaian narasi unik yang hadir dari masing-masing media sosial pada titik menarik, telah menceritakan pengalaman demi pengalaman setiap orang yang bersifat khas. Hal itu memantik kesamaan pengalaman dan referensi dari satu wisatawan dan wisatawan lainnya. Dari saling share dan pertukaran pengalaman itu, kekuatan promosi destinasi pariwisata di Indonesia telah berkembang menuju arah yang menggembirakan.

\section{Virtual Reality: Titik Terjauh Destinasi}

Mencermati konten media baru yang produksi pesannya dikoordinir dan dikuasai oleh instansi pemerintah itu akan menghadirkan prasangka unik. Dari sisi kesadaran tentang stereotip pemerintah, kita sendiri selalu mudah untuk menjatuhkan vonis bahwa apa saja yang dikendalikan oleh negara, pada dasarnya cenderung tidak beres. Ini masalah penelitian ini. Sebagai peneliti saya berupaya keras untuk mendisiplinkan diri agar anarsir pikiran itu bisa ditepis. Maka saya hanya berupaya untuk menjernihkan strategi analisis saya atas proposisi utama penelitian ini. Adapun proposisi yang saya pegang dari awal adalah telah terjadi pergeseran makna tentang tempat-tempat destinasi wisata di dua wilayah terpilih, jika kita memperhatikan konten website resmi sebagai sebuah media promosi. Pergeseran makna itu tidak semata-mata menjadi sebuah kealpaan atau kesengajaan, melainkan karena sifat media baru yang tanpa disadari membawa pada kebiasaan bermedia (media habit) yang unik.

Aspek produksi dalam konteks komunikasi digital memiliki peran penting mengingat model komunikasi pariwisata di Indonesia masih tetap menggunakan logika linear. Artinya, melihat bagaimana pengelolaan komunikasi wisata di Indonesia haruslah kembali dengan logika media old menurut Miller tadi. Logika media old ini berarti bahwa dalam beberapa situs dan website resmi yang dikelola oleh unsur pemerintah, masih terdapat paradigma informasi merekalah yang paling layak dipercaya untuk menggambarkan realitas dan kondisi di sebuah destinasi. Nampak sedikit naif di tengah mereka sendiri menyadari bahwa pada abad ini, setiap orang memiliki spirit demokrasi untuk mengakses dari media mana saja atas sebuah destinasi wisata. Uniknya, kenyataan itu tidak membuat aparat pemerintah untuk mengendurkan proses produksi konten website mereka. Beberapa konteks kebijakan layak untuk dipahami. Pengelolaan sebuah website pada dasarnya berarti anggaran keuangan yang kontinyu digelontorkan setiap tahun. Pemerintah kabupaten maupun provinsi memiliki kepentingan untuk membelanjakan biaya pengelolaan website tadi. Alasan itu pula yang membuat polarisasi website destinasi wisata yang dikelola beberapa pemerintah di Indonesia tidak bisa dipukul sama. Namun ironisnya, alasan itu pula yang digunakan untuk menoleransi begitu banyaknya bias makna dalam produksi konten media baru pengelola destinasi wisata. Salah satunya yang terjadi adalah seperti konten website di bawah ini. 


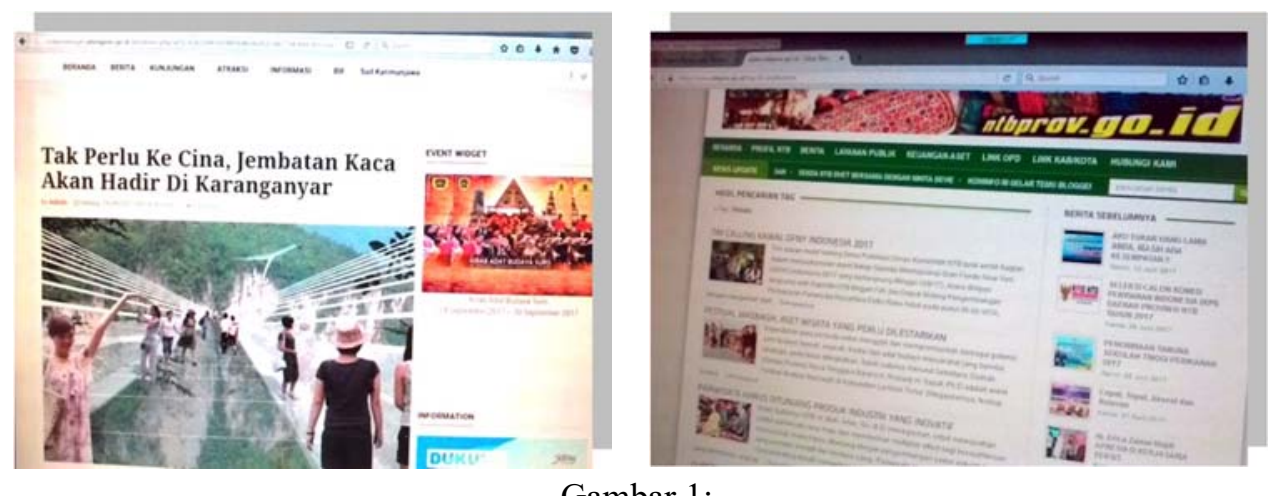

Gambar 1:

Salah satu contoh laman utama terteliti situs pariwisata

Provinsi Jawa Tengah, dan Provinsi Nusa Tenggara Barat

Situs di sebelah kiri memuat informasi yang menarik. Pengelola situs nampaknya sangat bersemangat untuk memberitahukan tentang akan lahirnya sebuah destinasi wisata baru di wilayah Karanganyar, Jawa Tengah. Sebuah kabupaten yang bersebelahan dengan kota Solo. Kabupaten Karanganyar merupakan kabupaten pemilik beberapa destinasi wisata yang bagus. Sebut saja wisata area dingin Tawangmangu, dengan beberapa air terjun kebanggaan mereka. Lalu situasi pedesaan dan perkebunan teh yang sangat eksotik dibeberapa ribu kaki ketinggiannya di atas permukaan laut. Namun menariknya, di tengah informasi yang sangat menarik untuk dipromosikan itu tadi, gambar yang dimunculkan di laman depan situs mereka adalah foto yang sama sekali tidak mewakili gambar destinasi yang dijanjikan. Foto yang diunggah oleh admin situs resmi pemerintah provinsi Jawa Tengah tersebut justru foto "Jembatan Kaca" yang ada di Cina, yakni jembatan kaca terpanjang di provinsi Zhangjiajie, Hunan. Terlepas dari apa motif mereka dalam menggunakan foto tersebut, namun publik netizen pada dasarnya mudah mengasosiasikan foto tadi dengan kemegahan jembatan yang ngarainya pernah menjadi tempat pengambilan gambar film Avatar itu. Namun nampaknya opini para netizen tidak terlalu menjadi masalah bagi admin bersangkutan. Terbukti hingga penelitian ini selesai dilaksanakan, foto tersebut masih tetap terpasang pada judul yang sama. Proses promosi yang bombastis membuat admin lupa bahwa iklan sebuah destinasi wisata dalam bentuk berita tidaklah sama dengan iklan produk dan jasa di dunia bisnis.

Sebenarnya jembatan yang diidentifikasi sejajar dengan jembatan kaca di Cina itu hanyalah sebuah wahana yang melekat pada sebuah destinasi wisata pengembangan kawasan perkebunan teh di desa Kemuning, Kecamatan Ngargoyoso, yang menjadi proyek bersama antara Pemerintah Kabupaten Karanganyar dengan Yayasan Rumpun Diponegoro. Jembatan kaca itu menjadi salah satu wahana berujud jembatan yang dibuat dengan bahan kaca dengan panjang 70 meter dengan ketinggian 30 meter. Bandingkan dengan jembatan kaca sepanjang 430 meter melintasi jurang Grand Canyon Zhangjiajie di Hunan yang membentang di ketinggian 300 meter. Apa yang didapatkan adalah nuansa hiperbola, mengarah pada hiperrealitas. Namun rata-rata 
pembaca dan penikmat situs resmi tadi tidak menganggap itu sebuah masalah yang berarti.

Hiperrealitas dalam menyajikan informasi di media baru nampaknya telah menjadi semacam kebiasaan bagi netizen. Sekali lagi, jika yang melakukan itu adalah seorang penulis di blogspot.com logikanya tidak akan jadi masalah. Namun bagaimana jika yang melakukan itu adalah admin di sebuah situs dan website resmi dari sebuah institusi pemerintah. Secara otomatis publik netizen akan mendapatkan informasi yang setara dengan hoax. Pada titik inilah menyikapi pemuatan gambar tadi tidak bisa ditelusuri dari perspektif etika media. Dunia virtual reality memiliki hukumnya sendiri. Bagi Mark T. Palmer (1995) dunia virtual itu sejajar dengan insting mendasar manusia dalam melakukan proses komunikasi interpersonal. Ada hukum tertentu yang membuat dunia virtual dalam komunikasi digital menjadi sekadar perpanjangan tangan dari komunikasi interpersonal termediasi melalui rangkai perangkat internet. Lebih jauh Palmer menulis

In the information age, humans come to know one another and form bonds in a variety of contexts and through a variety of media. Individuals are finding ways to adapt the essential features of interpersonal relationships to the changing features of available media technologies. This interactions has never been so important as now when conducting personal and private relationship with other via computer-based channels is not a remote possibility, but a current reality

(Palmer, 1995:277)

Seperti pengakuan Palmer, bahwa hubungan antar manusia nantinya akan tergantikan dengan perangkat teknologi komputer dan komunikasi. Namun esensi hubungan yang menarasikan kebutuhan manusia tidaklah pernah berubah. Inilah esensi mengapa kemudian konten di media sosial dan di media resmi website pemerintah tentang destinasi wisata bisa abai dengan kesalahan informasi dan kekeliruan kerja jurnalistik. Termasuk perilaku asal comot tanpa harus memperhatikan urgensi berita dan asal sumber kerja jurnalistik. Gambar di bawah ini menunjukan cara kerja demikian. 


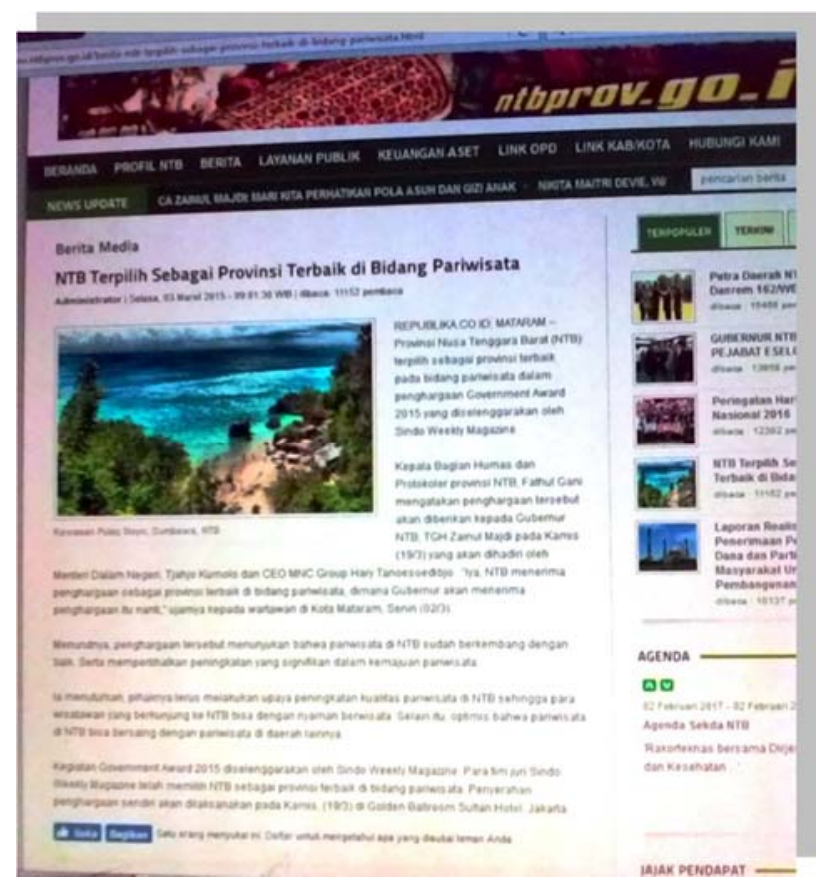

Gambar 2:

Petikan Berita Media hasil dari copy paste Karya Jurnalistik di laman ntbprov.go.id

Gambar di atas berasal dari salah satu laman utama situs resmi pemerintah provinsi NTB. Momen yang diangkat adalah ketika pada tahun 2015 provinsi itu terpilih menjadi provinsi terbaik di Indonesia dalam bidang pariwisata. Tentu saja pemerintah dan publik masyarakat di sana bangga. Manifestasi kebanggaan itu dimunculkan dalam bentuk upload salah satu pemberitaan media digital tentang penghargaan tersebut. Berita tentang keberhasilan pariwisata NTB tadi diambil dari Republika.co.id. dengan seluruh batang tubuh berita, tanpa melalui sensor sama sekali. Dari pemberitaan tadi nampak bahwa framing yang ingin dibentuk adalah memunculkan sinergi endorser dari pihak ketiga yang memberitakan keberhasilan NTB. Dari sudut pandang strategi promosi hal ini sangat baik, mengingat tentu saja menjadi aneh apabila pihak pemerintah provinsi sendiri yang berkoar-koar mengakui bahwa mereka telah keluar sebagai juara. Pemerintah provinsi NTB telah bertindak sebagai penentu narasi atas keberhasilan provinsi mereka.

\section{E. SIMPULAN}

Tulisan ini menyajikan sebuah fenomena unik dalam bidang komunikasi destinasi wisata. Merebaknya media digital dengan beragam platform yang tersedia membuat aktivitas bermedia setiap orang mengalami revolusi sedemikian rupa. Perubahan media habit itu memberikan kontribusi unik terhadap strategi komunikasi pemasaran destinasi wisata. Penelitian atas teks laman dua website pemerintah provinsi (Jawa Tengah dan Nusa Tenggara Barat) di Indonesia khususnya tentang destinasi mereka ini, telah menemukan 
beragam fakta menarik. Temuan itu terbagi atas prinsip proses pengelolaan sebuah website, hingga bagaimana sebuah promosi atas destinasi wisata di sebuah wilayah berkelindan sedemikian rupa dengan tradisi naratif para pengunjung wisata yang secara tak sadar menceritakan pengalaman wisata mereka di sebuah tempat. Perilaku bermedia itu kemudian menjadi sebuah praktek kontributif terhadap perkembangan komunikasi pemasaran pariwisata. Hasilnya adalah muncul beragam interpretasi yang bersifat subjektif atas makna-makna sebuah tempat destinasi wisata. Jika pada laman resmi sebuah tempat wisata selama ini hanya ditemukan satu tafsir yang berupaya menggambarkan sebuah destinasi, maka melalui kegemaran produksi konten di laman pribadi masing-masing, lalu melakukan share atas konten itu di media sosial, dunia pariwisata benar-benar berada dalam kondisi baru.

Kebutuhan untuk menarasikan secara pribadi setiap objek destinasi wisata menghadirkan struktur narasi berikut bingkai makna yang unik dalam setiap aktivitas netizen. Konteks itu pula yang membuat laman resmi sebuah otoritas pengelola situs destinasi wisata sebuah wilayah akan sangat nampak konvensional dan mengada-ada. Perkembangan media digital yang lebih bersifat personal pada titik tertentu membuat makna sakral sebuah tempat destinasi wisata dengan sendirinya teredusir sedemikian rupa. Ini adalah proses desakralisasi peran penerjemah 'nilai' atas sebuah makna destinasi wisata. Jika pada masa lalu peran para opinion leader, pemuka masyarakat, arkeolog, pejabat tinggi pemerintah, memiliki kuasa untuk menerjemahkan makna dan nilai sebuah destinasi wisata, maka pada abad millennial ini setiap orang yang memiliki laman pribadi, ada hakekatnya bisa menghadirkan narasi sendiri. Narasi tentang destinasi itulah yang mungkin bisa sangat berbeda dengan narasi mainstrem. Terjadi keragaman makna di sana. Meskipun dalam konteks strategi komunikasi pariwisata, apa yang dilakukan oleh para wisatawan melalui media sosial mereka memberikan kontribusi positif, namun itu lebih semata pada pertimbangan ekonomis. Sementara pada sisi substantif kebermaknaan sebuah destinasi wisata akan terus mengalami perkembangan dan perubahan sedemikian rupa. Sifat variabilitas ini akan terus mewarnai perkembangan komunikasi pariwisata di Indonesia.

\section{DAFTAR PUSTAKA}

Bungin, Burhan, (2015). Komunikasi Pariwisata: Pemasaran dan Brand Destinasi, Edisi Pertama, Jakarta: Prenadamedia Group.

Byon, K. K., \& Zhang, J. J. (2009). Development of a scale measuring destination image. Journal Marketing Intelligence \& Planning, 28(4), 508-532.

Cakim, I. M. (2010).Implementing Word of Mouth Marketing. New Jersey: John Wiley \& Sons.

Chiu, H. Y. (2007). Brand USA: Democratic propaganda in the third social space. The Whitehead Journal of Diplomacy and International Relations. Diaksesdari www.journalofdiplomacy.org

Danesi, Marcel, (2010). Pesan, Tanda, dan Makna: Buku Teks Dasar Mengenai Semiotika dan Teori Komunikasi, Penerjemah Evi Setyarini dan Lusi Lian Piantari, Yogyakarta: Jalasutra. 
Dinnie, K., Melewar, T. C., Seidenfuss, K. U., \& Musa Ghazali. (2010). Nation Branding and Integrated Marketing Communication: An ASEAN perspective. Journal International Marketing Review, 27(4), 388-403.

Eberle, T.S. (1992). A new paradigm for the sosiology of knowledge: " The social construction of reality" after 25 years. Journal Schweizerisch Zeitschrift fur Soziologie: Review Suisse de Sociologie, 18, hal. 493-502.

Eymeren, Margawati van, (2013). Informasi Teknologis: Antropologi Teknologis Berdasarkan Pemikiran Albert Borgmann dan Walter J. Ong, Jakarta: Pusat Kajian Filsafat dan Pancasila.

Fanggy, T. S., \& Richardson, S. (2011), July. An Analysis on International Tourist' Perceptions Towards Destination Branding: "Visit Indonesia 2008” Marketing campaign. KertasKerjadibentangkanpada The 2nd International Research Symposium in Service Management, Yogyakarta, Indonesia.

Fill, Chris., (2013). Marketing Communication, Brand, Experiences and Participation, Sixth Edition. Harlow: Pearson.

Gamson, W. A., Croteau, D., Hoynes, W., \& Sasson, T. (1992). Media Images and Social Construction of Reality. Journal Annual Review of Sociology, 18, hal. 373-393.

Gertner, R. K., Berger, K., \&Gertner, D. (2006). Country-dot-com: Marketing and Branding Destination online. Journal of Travel \& Marketing, 21(2/3), 105-116.

Goldsmith, R.E. (2006). Electronic word-of-mouth, in Khosrow-Pour, M. (Ed.), Encyclopedia of ECommerce, E-Government and Mobile Commerce, pp. 408-12. Hershey, PA: Idea GroupPublishing.

Hacking, I.(2000). The Social Construction of What. Harvard: Harvard College.

Hankinson, G. (2004). The Brand Images of Tourism Destination: A Study of the Saliency of Organic Images. Journal of Product \& Brand Management, 13(1), 6-14.

Hankinson, G. (2005). Destination Brand Images: A Business Tourism Perspective. Journal of Service Marketing, 19, 24-32.

Hansen, A., \& Machin, D. (2008). Visually branding the Environment: Climate Change as a Marketing Opportunity. Journal Discourse Studies, 10(6), 777-794.

Haryatmoko, (2007). Etika Komunikasi: Manipulasi Media, Kekerasan, dan Pornografi, Yogyakarta: Kanisius.

Haven-Tang, C., Jones, E., \& Webb, C. (2007). Critical success factors for business tourism destination: Exploiting Cardiff's national capital city status and shaping its business tourism offer. Journal Travel \& Tourism Marketing, 22(3/4), 45-59.

Hennig-Thurau, T., Gwinner, K. P., Walsh, G. and Gremler, D. D. (2004). Electronic wordof-mouth via consumer-opinion platforms: what motivates consumers to articulate themselves on the Internet? Journal of Interactive Marketing.Vol. 18 No. 1, pp. 3852.

Holiday, Ryan., (2012). Trust Me I'm Lying: Confessions of A Media Manipulator, New York: Penguin Group.

Hosany, S., Eksel, Y., \&Uysal, M. (2007). Destination Image and Destination Personality: An Application of Branding Theories to Tourism Places. Journal of Business Research, 59, 638-642. 
Huang, S. (2011). Nation-Branding and Transnational Consumtion: Jepang-Mania and the Korean Wave in Taiwan. Journal Media, Culture, \& Society, 33(1), 3-18.

Humaira, Aulian dan Lili Adi Wibowo. (2016). Analisis Faktor Electronik Word of Mouth (EWOM) dalam Mempengaruhi keputusan Berkunjung Wisatawan. Jurnal Tourism and Hospitality Essentials (THE) Journal, Vol. VI, No. 2, 2016 - 1052.

Insch, A. (2011). Conceptualization and anatomy of green destination brands. International Journal of Culture Tourism and Hospitality Research, 5(3), 282-290.

Ismagilova, Elvira. - . Electronic Word of Mouth (eWOM) in the Marketing Context.Inggris : Springer.

Jarvis, Jeff., (2010). What Would Google Do?, Penerjemah Haris Priyatna, Jakarta: Ufuk Press.

Kartajaya, Hermawan, \& Bayu Asmara, (2014). Wow Service is Care, Jakarta: PT Gramedia Pustaka Utama.

Kartajaya, Hermawan. (2015). Indonesia WOW, Markplus WOW, We are WOW, Jakarta: PT Gramedia Pustaka Utama.

Kartajaya, Hermawan., (2006a). On Marketing. Jakarta: PT Gramedia Pustaka

Kartajaya, Hermawan., (2006b). On Marketing mix. Bandung: Penerbit Mizan

Kayat. Kalsom., (2008). A Study on the Effectiveness of Visit Malaysia Year 2007, Final Report. (Unpublished research report). Research and Innovation Management Centre Universitas Utara Malaysia, Sintok.

Kotler, Philip, Hermawan Kartajaya, Hooi Den Huan, (2017). Marketing for Competitiveness: Asia yang Mendunia pada Era Konsumen Digital!, Yogyakarta: Bentang Pustaka.

Kotler, Philip, Hermawan Kartajaya, Iwan Setiawan, (2010). Marketing 3.0: Mulai dari Produk ke Pelanggan ke Human Spirit, Penerjemah Dian Wulandari, Jakarta: Erlangga.

Kotler, Philip. (2000). Marketing Management: The Millennium Edition, Upper Saddle River, NJ: Prentice-Hall.

Kotler, Philip. (2006). Marketing Management: Analysis, Planning, Implementation, and Control. New Jersey: Prentice Hall.

Kotler, Philip., \& Pfoertsch, W. (2006). B2B Brand Management. Jakarta: Erlangga.

Loo, T., \& Davies, G. (2006). Branding China: The Ultimate Challenge in Reputation Management. Cooperate Reputation Review, 9(3), 198-210.

Lucarelli, A., \& Berg, P. O. (2011). Citi branding: A State-of-the-art Review of The Research Domain. Journal of Place Management and Development, 4(1), 9-27.

Martin, D., \& Woodside, A. G. (2011). Storytelling Research on International Visitors: Interpreting own Experiences in Tokyo. Qualitative Market Research: An International Journal, 14(1), 27-54.

Marzano, G. (2006). Relevance of Power in the Collaborative Process of Destination Branding. Paper Presented at $11^{\text {th }}$ Annual Conference on Graduate Education and Graduate Student Research in Hospitality and Tourism, Seattle, USA.

Marzano, G., \& Scott, N. (2005). Stakeholder Power in Destination Branding: A Methodological discussion. Proceedings of The International Conference on

$140 \mid$ Muhamad Sulhan 
Destination Branding and Marketing for Regional Tourism Development, Macau S.A.R. China (pp. 203-213)

McCartney, G. 2008. The CAT (Casino Tourism) and MICE (Meeting, Incentive, Conventions, Exhibitions): Key Development Considerations for the Convention and Exhibition Industry in Macau. Journal Convention \& Event Tourism, 9(4), 293-307.

McCartney, G., Butler, R., \& Bennett, M. 2008. A Strategic Use of Communication Mix in the Destination Image-Formation Process. Journal of Travel Research, 47(2), 183-196.

Miller, Vincent., (2011). Understanding Digital Culture, London: Sage Publications Ltd.

Mokalu, Andre., (2017). Soul Travellers: Turning Miles into Memories, Jakarta: PT Gramedia Widiasarana Indonesia.

Morgan, N., Pritchard, A., \& Pride, R. (2011). Destination branding: Managing Place Reputation ( $3^{\text {rd }}$ ed.). Amsterdam: Elsevir.

NorhafezahYusof. (2008). Cyberjaya: The making of a high-tech city (Unpublished doctoral dissertation). Nottingham Trent University, UK.

Osei, C., \& Gbadamosi, A. (2011). Re-branding Africa. Journal Marketing Intelligence \& Planning, 29(3), 284-304.

Pike, S, Bianchi, C., Kerr, G., \& Patti, C.2010. Consumer-based Brand Equity for Australia as a Long-Haul Tourism Destination in an Emerging Market..Journal International Marketing Review, 27(4), 434-449.

Pike, S. (2005). Tourism Destination Branding Complexity. Journal ofProduct \&Brand Management, 14(4), 258-259.

Prakash, Satya., (2007). Tourism Malaysia: Creating "brand Malaysia”. Paper presented at ICFAI Center Management Research, Hyderabat.

Pucsko, L., Razt, T., \& Smith, M. (2007). Old city, new image: Perception, positioning, and promotion of Budapest. Journal of Travel \& Tourism Marketing, 22(2), 21-34.

Rossiter, John R., dan Steven Bellman,. (2005). Marketing Communication: Theory and Application. French Forest: Pearson Prentice Hall.

Ruzzier, M. K. (2010). Extending the tourism destination image concept into costumerbased brand equity for a tourism destination. Journal Ekonomska Intrazivanja, 23(3), 24-42.

Ryan, J., \& Silvanto, S. (2010). World heritage sites: The purposes and politics of destination branding. Journal of Travel \& Tourism Marketing, 27, 533-545.

Saraniemi, S. (2011). Destination brand identity development and value system. Journal Tourism Review, 65(2), 52-60.

Schmidt, Eric, \& Jared Cohen (2014). The New Digital Age: Cakrawala Baru Negara, Bisnis, dan Hidup Kita, Penerjemah Selviya Hanna, Jakarta: Kepustakaan Populer Gramedia.

Setiadi, Idham Bachtiar, 'Warisan Budaya, Sikap Ilmiah, dan Kritik Kebudayaan' Jurnal Prisma, Mengelola Cagar Budaya, Merawat Peradaban, Volume 36, 2007, hal. 64-70. 
Simanjuntak, Bungaran Antonius, Flores Tanjung, dan Rosramadhana Nasution, (2017). Sejarah Pariwisata: Menuju Perkembangan Pariwisata Indonesia, Jakarta: Yayasan Pustaka Obor Indonesia.

Simpson, P. M., \& Sigiuaw, J. A. (2008). Destination word of mouth: The role of traveler type, resident, and identity salience. Journal of Travel Research, 47(2), 167-182.

Smiers, Joost, (2009). Arts Under Pressure: Memperjuangkan Keanekaragaman Budaya di Era Globalisasi, penerjemah Umi Haryati, Yogyakarta: InsistPress.

Steve, Clement,. (2014). Menyusuri Garis Bumi: Catatan Perjalanan dari Gunung ke Gunung, dari Lembah ke Lembah, Jakarta: PT Grasindo.

Tanudirjo, Daud Aris, (2017). Peran Arkeologi dalam Kebijakan Pengelolaan Cagar Budaya di Indonesia, dalam Jurnal Prisma, Mengelola Cagar Budaya, Merawat Peradaban, Volume 36, , hal. 3-17.

Tubss, Stewart L., \& Sylvia Moss,. (2000). Human Communication: Konteks-konteks Komunikasi, Penerjemah Deddy Mulyana dan Gembirasari, Bandung: PT Remaja Rosdakarya.

Vellas, F., \& Becherel, L. 2008. Pemasaran Pariwisata Internasional: Sebuah Pendekatan Strategis. Jakarta: Yayasan Obor Indonesia.

Vitic, A., \& Ringer, G. 2007. Branding post-conflict destination: Recreating Montenegro after the disintegration of Yugoslavia. Journal of Travel and Tourism Marketing, $23(2 / 3 / 4), 127-137$.

Wan, P. Y. K., \& Cheng, E. I. M. 2011. Service quality of Macau's world heritage site. International Journal of Culture, Tourism, and Hospilality Research, 5(1), 57-68.

Wang, Y. (2008). Collaborative destination marketing, understanding the dynamic process. Journal od Travel Research, 47(2), 151-166.

Wilhelm, Anthony G., (2000). Demokrasi di Era Digital: Tantangan Kehidupan Politik di Ruang Cyber, Penerjemah N. Veraningtyas, Yogyakarta: Pustaka Pelajar.

Wilson, J. A. J., \& Liu, J. 2011. The challenges of Ilsamic branding: Navigating emotions and halal. Journal of Ilsamic Marketing, 2(1), 28-42.

Wisansing, J. 2005. Components of destination branding: A case of Malaysia. Diaksesdarihttp://www.ttresearch.org/home/images/2553 4/6.pdf.

Yananda, M. Rahmat, \& Ummi Salamah, (2014). Branding Tempat: Membangun Kota, Kabupaten, dan Provinsi Berbasis Identitas, Jakarta Selatan: Makna Informasi.

Yulianto, Kresno, (2016). Di Balik Pilar-pilar Museum, Jakarta: Wedatama Widya Sastra. 